\title{
Glacier area and mass changes since 1964 in the Ala Archa Valley, Kyrgyz Ala-Too, northern Tien Shan
}

\author{
(C) 2015 r. T. Bolch ${ }^{1,2}$ \\ ${ }^{1}$ Geographisches Institut, Universität Zürich, Switzerland; ${ }^{2}$ Institut für Kartographie, Technische Universität Dresden, Germany \\ tobias.bolch@geo.uzh.ch
}

\section{Изменение площади и массы ледников в долине Ала-Арча в Киргизском хребте на Северном Тянь-Шане с 1964 г.}

\author{
Т. Больх ${ }^{1,2}$ \\ ${ }^{1}$ Институт географии Цюрихского университета, Швейцария; \\ ${ }^{2}$ Институт картографии Технического университета в Дрездене, Германия
}

Статья принята к печати 8 сентября 2014 г.

ASTER, Corona, Digital Terrain Model (DTM), Geodetic Mass Balance, Glacier Change, Rapid Eye, Tien Shan.

Геодезический баланс массы, изменения ледников, спутник Согопа, Тянь-Шань, цифровая модель поверхности (DTM), ASTER.

Glaciers are an important source of fresh water for Central Asia as they release water during the summer months when precipitation is low and water demand highest. Many studies address glacier area changes but only changes in glacier mass can be directly linked to climate and runoff. Despite the importance, investigations of glacier mass changes have been restricted to only a few glaciers in the Tien Shan until now. Geodetic mass balance measurements are suitable to complement and extend existing in-situ measurements. In this study, both area and mass changes of the $\sim 40 \mathrm{~km}^{2}$ glacier ice in the Ala Archa Valley, Kyrgyz Tien Shan, were investigated using 1964 and 1971 stereo Corona, 2012 stereo ASTER, the SRTM digital terrain model and other optical data such as Landsat ETM+ or Rapid Eye. In addition, ice thickness was modeled taking the basal shear stress and the glacier surface topography into account. The results indicate an area loss of $18.3 \pm 5.0 \%$ from 1964 until 2010 with continuous shrinkage in all investigated periods. The glacier's mass balance was $-0.45 \pm 0.27 \mathrm{~m}$ w.e. $\mathrm{a}^{-1}$ for the period $1964-1999$ and $-0.42 \pm 0.66 \mathrm{~m}$ w.e. $\mathrm{a}^{-1}$ for $1999-2012$. Golubin Glacier showed a possible slight mass gain for $1964-$ 1971 and a decelerated mass loss for the 1999-2012 period. This is in good agreement with existing in-situ measurements exiting from 1962 until 1994 and since 2010. The overall ice volume was estimated to be $1.56 \pm 0.47 \mathrm{~km}^{3}$ of ice in the year 2000 . Hence, the entire ice would be lost by 2100 if the mass loss would continue at the same rate.

Дана оценка изменения площади и массы ледников в долине Ала-Арча в Киргизском Тянь-Шане с помощью стереоснимков спутника Соrona 1964 и 1971 гг., стереоснимков ASTER 2012 г., цифровой модели земной поверхности SRTM и других оптических данных. С 1964 по 2010 г. ледники

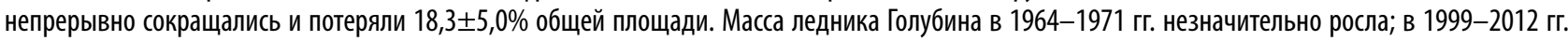
его сокращение замедлилось.

\section{Introduction}

The Tien Shan and its cryosphere is the origin of the large rivers Amu-Darya, Syr-Darya, Chu, Ili or Tarim which contribute to huge endorheic lakes like Aral Sea or Lake Balkhash or terminate in the steppe or desert. These rivers are the artery for the region and, in addition, many large cities like Urumchi/Xinjiang, China, Tahskent/Uzbekistan, Almaty/ Kazakhstan or Bishkek, the capital of Kyrgyzstan are located on the foothills of this mountain range and directly depend on the runoff from nearby mountains. Runoff from glaciers is especially important in summer and early autumn when the water demand is high and the seasonal snow of the mountains melted. No certain numbers about the share of glacier melt to the overall runoff exist but estimates show an average annual contribution of less than $10 \%$ for Syr-Darya and about $40 \%$ for the Tarim River [47]. Modelling results of glacier runoff in different basins of the Tien
Shan show first an increase of runoff with temperature increase followed by a reduction with the continued glacier shrinkage even with continuous temperature rise [29]. It is therefore of high importance to study the ice storage of the glaciers and their past and possible future evolution.

The temperature increased on average since the 1950s accompanied by a slight but not significant increase in precipitation in most parts of the Tien Shan $[2,6,11]$. Concomitantly, glaciers of the Tien Shan shrank like in many other parts of the world since the little ice age [46] with a pronounced recession in the last decades $[2,3,7,11,20,31]$. The detected area loss since the 1950s is higher in the more humid areas in northern Tien Shan than in the more arid regions of the central and eastern Tien Shan [34, 47]. Declassified imagery from the 1960s and 1970s were found to be suitable to extend the analysis back in time and to evaluate glacier outlines based on topographic maps [10, 14, 35, 36]. 
Area changes show an indirect signal to climate while the glacier mass balance can more directly be related to climate and hydrology. Existing mass balance measurements in the Tien Shan indicate a pronounced mass loss since the mid-1970s which is highest at Tuyuksu Glacier situated in Ile Alatau (also: Zailijskij Alatau) at the northern margin of the Tien Shan [17, 50]. However, mass balance measurements exist just for a few glaciers and only Tuyuksu Glacier and Urumchi Glacier No. 1 in eastern Tien Shan were measured continuously. Several other measurements, such as at Abramov Glacier (Pamir Alay, southern Kyrgyzstan) and Karabatkak Glacier (Terskey Alatau) were interrupted since the collapse of the Soviet Union. Between 1968 and 1994 in-situ measurements were also performed at Golubin Glacier in Ala Archa Valley/ Kyrgyz Alatau [1, 50]. The mass balance was found to be predominantly negative. Mass balance measurements at Golubin Glacier were re-established in 2010 and showed a slightly positive value for 2010/2011 [50]. However, no mass balance information exists between 1994 and 2010 .

Geodetic mass balance estimations are suitable to evaluate, complement and extend existing in-situ measurements $[15,51]$. National digital elevation models (DEMs), the near global SRTM3 DEM, as well as DEMs derived from optical stereo data such as SPOT, ASTER or Corona were found to be suitable for this task [9, 15, 41]. However, careful co-registration and an estimation of the penetration of the SRTM C-band radar beam into snow and ice are required to reduce uncertainties [12, 24, 37, 42].

A prerequisite for hydrologic and glaciological modelling purposes is not only the knowledge about the change in volume but also about the glacier volume and its distribution over the glaciers. The glacier thickness can be measured in the field e.g. using ground penetrating radar (GPR). This is, however, only feasible for a small numbers of glaciers. Simple models are required to estimate the current and future glaciers volume for a large number of glaciers simultaneously. Promising approaches to model the glacier bed topography based on the surface topography, glacier outlines and possibly additional information about glacier mass turnover and the mass balance gradient [22, 33].

The aim of this study is (1) to reassess and extend in time the presented data about area changes in Ala Archa Valley [7] and (2) present estimations about the absolute glacier volume and glacier mass changes for different periods between 1964 and 2012 using remote-sensing derived information.

\section{Study area}

The Kyrgyz Ala-Too (Kyrgyz Range) represents the north-western part of Tien Shan with an east-west extent of over $400 \mathrm{~km} \mathrm{[5].} \mathrm{The} \mathrm{water} \mathrm{released} \mathrm{at} \mathrm{the}$ northern slope drains into the river Chu which is the main artery for the (semi-) arid lowlands in Kyrgyzstan and Kazakhstan including Bishkek, the capital of Kyrgyzstan. At its northern slope, $40 \mathrm{~km}$ south of Bishkek, the study area of this work can be found: the Ala Archa National Park $\left(74^{\circ} 24^{\prime}\right.$ E - $74^{\circ} 34^{\prime}$ E; $42^{\circ} 24^{\prime} \mathrm{N}-42^{\circ} 36^{\prime} \mathrm{N}$, Fig. 1). This nature reserve was established in 1976 and constitutes a total area of $194 \mathrm{~km}^{2}$ and extends along the Ala-Archa river basin and the surrounding with altitudes ranging from $1,500 \mathrm{~m}$ at its entrance up to 4,895 $\mathrm{m}$ at Semenova-Tyan-Shanskogo Peak. Glaciers cover an area of $\sim 33.3 \mathrm{~km}^{2}$ and extend over an altitude range of 3,310-4,760 $\mathrm{m}$ (2010). The annual precipitation increases from less than $400 \mathrm{~mm}$, measured at Bishkek station at an elevation of $771 \mathrm{~m}$ asl., to about $700 \mathrm{~mm}$ at the glaciers [1]. The maximum precipitation occurs in late spring to early summer (see Fig. 1).

\section{Data and methods}

Declassified stereo Corona KH-4A and KH-4B images were used to obtain the glacier area and surface elevation for the years 1964 and 1971 (Table 1). Corona was a spy satellite mission operating from 1960 until the mid-1970s and was mainly designed to acquire images of the former USSR and other communist countries, such as China [34]. The images have a relatively high resolution of $\sim 7 \mathrm{~m}(\mathrm{KH}-4)$ and up to $2 \mathrm{~m}(\mathrm{KH}-4 \mathrm{~B})$. The main disadvantages are the panoramic distortion and unstable acquisition parameters [19]. The utilized images were acquired at the end of the ablation season and had suitable sow conditions. Few clouds occurred at the 1964 images but all glaciers were cloud free except Golubin Glacier where the very distal part of the tongue was hidden. The 1971 data only cover a smaller part of the study region and only Golubin Glacier was investigated with the 1971 DTM data. Further data used are the widespread Landsat images which are freely available in an orthorectified level (www.usgs.gov). The most recent glacier extents were delineated from 2010 Rapid Eye data which has 

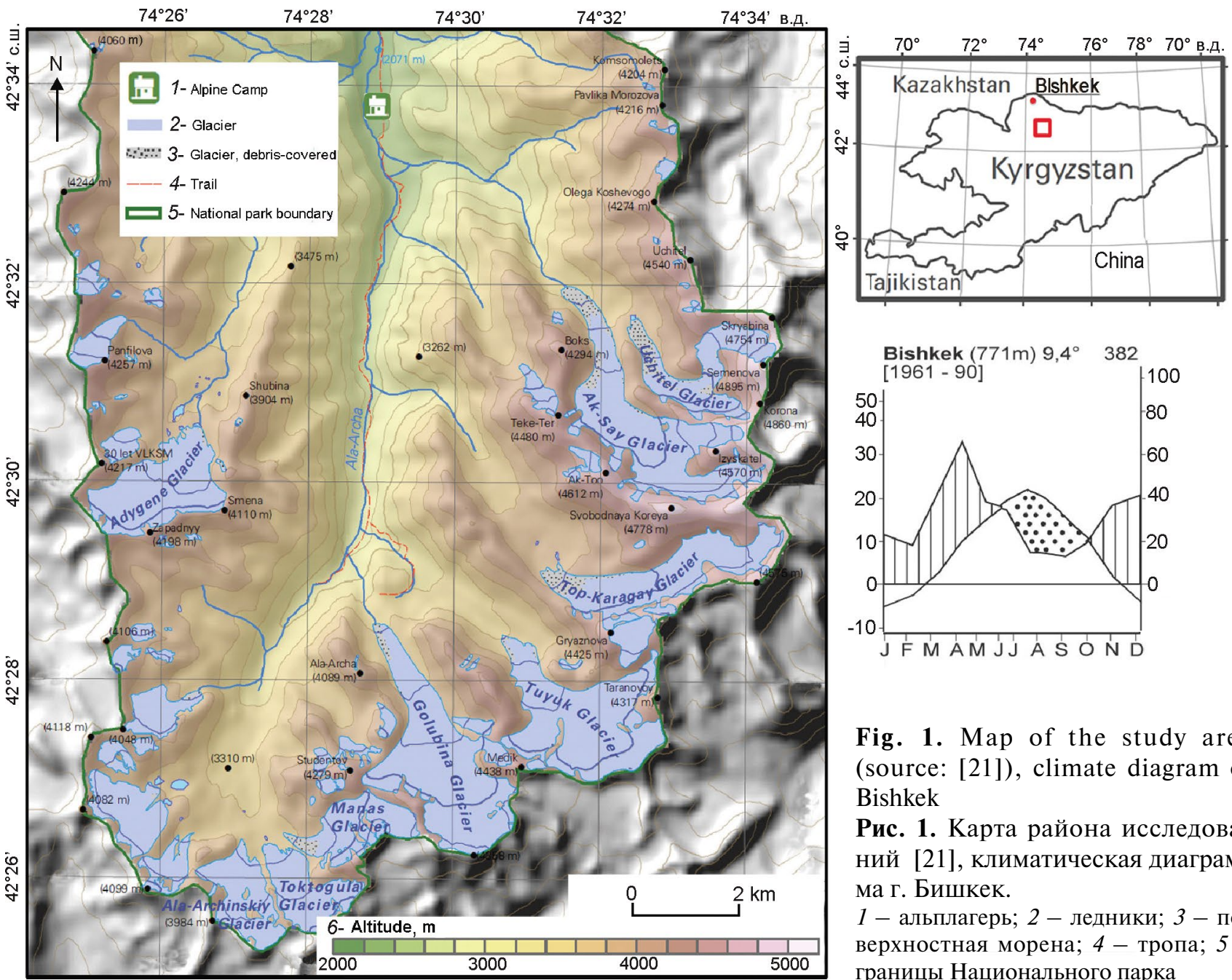

Fig. 1. Map of the study area (source: [21]), climate diagram of Bishkek

Рис. 1. Карта района исследований [21], климатическая диаграмма г. Бишкек.

1 - альплагерь; 2 - ледники; 3 - поверхностная морена; 4 - тропа; 5 границы Национального парка

Table 1. Utilized data

\begin{tabular}{|l|c|c|c|c|}
\hline \multicolumn{1}{|c|}{ Date } & Satellite/Sensor/Product & Resolution, $\mathrm{m}$ & Spectral characteristics & Usage \\
\hline 20.09 .1964 & Corona KH-4 & $\sim 7$ & Pan & Glacier delineation, DEM generation \\
\hline 16.09 .1971 & Corona KH-4B & $\sim 3$ & Pan & Glacier delineation, DEM generation \\
\hline 15.07 .1994 & Landsat TM & 30 & VNIR, SWIR, TIR & Glacier delineation \\
\hline February 2000 & SRTM C-Band (original) & 90 & - & Glacier surface elevation \\
\hline February 2000 & SRTM C-Band (void-filled) & 90 & - & Ice thickness \\
\hline 08.06 .2001 & Landsat ETM+ & $30 / 15$ & VNIR, SWIR, TIR, Pan & Reference, Glacier delineation \\
\hline $\begin{array}{l}01.08 .2003 \\
17.08 .2003\end{array}$ & Terra ASTER & 15 & VNIR, SWIR, TIR & Glacier delineation \\
\hline 06.09 .2010 & Rapid Eye & 6.5 & VNIR & Glacier delineation \\
\hline 2012 & Terra ASTER & 15 & VNIR, SWIR, TIR & Glacier surface elevation \\
\hline
\end{tabular}

a ground resolution of $6.5 \mathrm{~m}$. Stereo ASTER from 2012 and the original SRTM-C band DTM data with a resolution of 90 metre was used to estimate the mass changes in addition to the Corona data. All data were co-registered to the 2001 pan-sharpened
ETM+ scene. For the estimation of the glacier volume and the bed topography the void filled version of the SRTM DTM by the Consultative Group for International Agriculture Research Consortium for Spatial Information (CGIAR-CSI), version 4, was used. 

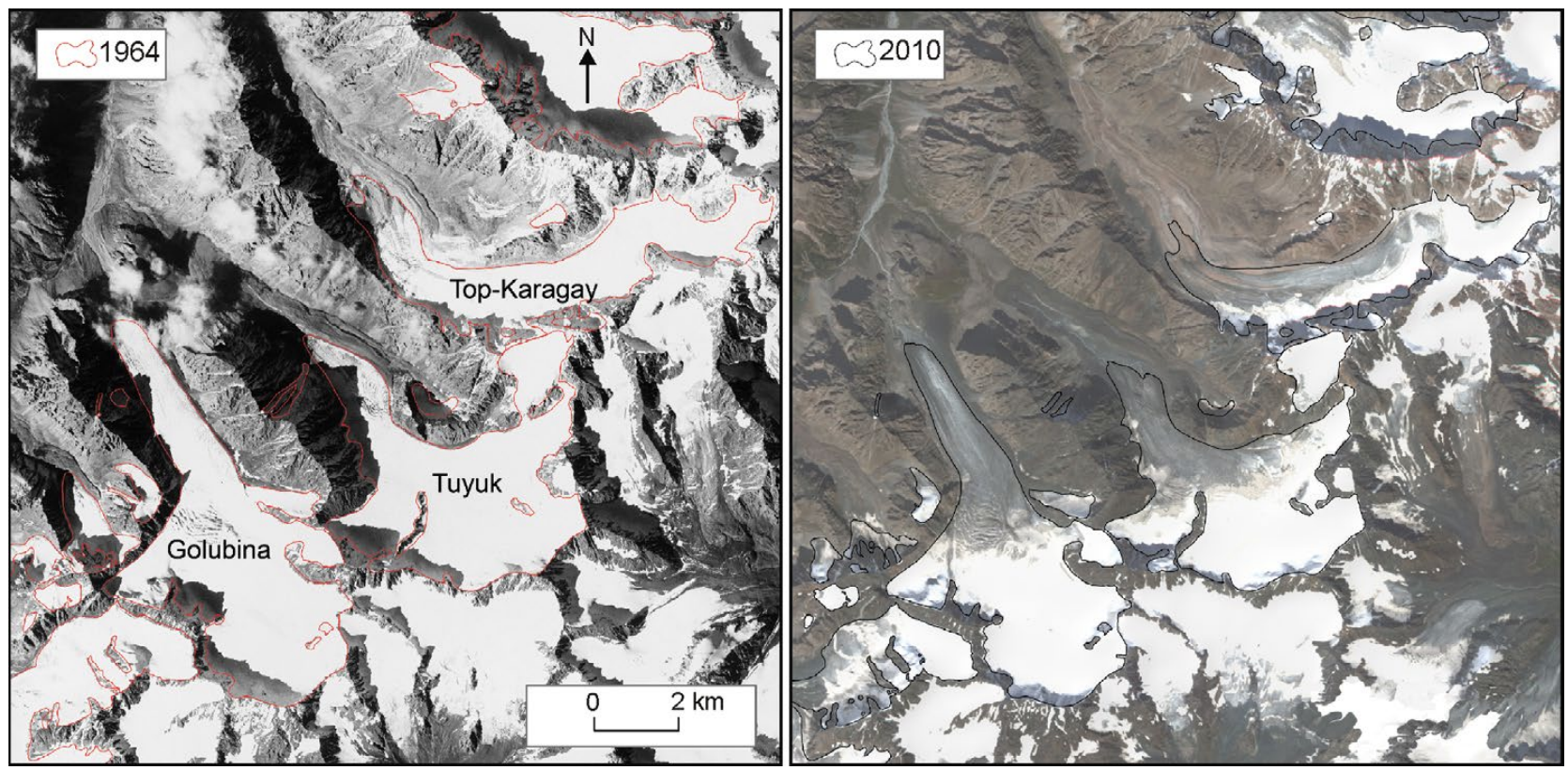

Fig. 2. Golubin, Tuyuk and Top-Karagay glaciers in 1964 (Corona KH-4A) and 2010 (Rapid Eye)

Рис. 2. Ледники Голубина, Туюк и Топ-Карагай в 1964 г. (Corona KH-4A) и 2010 г. (Rapid Eye)

Glaciers were delineated manually as most of the available scenes were panchromatic (Corona) or had no short-wave-infrared channel (RapidEye) which is needed for automation. A few glaciers had some debris cover at their tongues which made the correct identification not straight forward. Glacier melt water streams, the shaded relief, and a 2007 ALOS PALSAR coherence image [cf. 25], the difference image of the digital terrain models (DTMs) and the high resolution of the utilized imagery helped to identify the margin correctly (Fig. 2). We estimated the uncertainty based on the buffer method [cf. 13] choosing a buffer size of half a pixel for the well registered Landsat and Rapid Eye data and one pixel size for the Corona data. The resultant uncertainties vary between $2.2 \%$ for Corona $\mathrm{KH}-4 \mathrm{~B}$ and $8.2 \%$ for the Landsat TM data. This is within the range of previously reported uncertainties of semi-automated methods [13, 39, 40] and manual delineation [38].

The SRTM DTM was chosen as the master DTM for assessing volume changes as it was proven to be of suitable accuracy [23] and has been applied for many studies assessing glacier volume changes [e.g. 9, 42]. The original non-void filled version was used as no information about the data used for void filling was available. Most glaciers were not or only slightly affected by the data voids with the maximum of less than $30 \%$ voids in the upper accumulation area of one glacier. A DTM based on 2012 stereo ASTER data was automatically generated using PCI Geomatica to assess the recent mass changes. DTMs from stereo Corona data were generated using the Remote Sensing Software Package Graz (RSG) which has been proven to provide good results for Corona data [15, 42]. About 20 ground control points (GCPs) based on the 2001 Landsat scene were selected for each Corona scene. The automatically identified tie points (TPs) required for image matching were visually checked and manually improved if necessary. The final $x, y$ residuals of the GCPs varied between $\sim 15$ to $20 \mathrm{~m}$ and the $\mathrm{z}$-residual was $\sim 50 \mathrm{~m}$ for each scene [21]. These values are acceptable given the uncertain image acquisition parameters and the large panoramic distortion of the Corona images. Small data gaps occurred due clouds, cast shadow and snow cover in the accumulation regions of few glaciers but also in small areas in the ablation of Golubin and Ak-Say glaciers. Overall more than $80 \%$ of the glaciated terrain was covered by the 1964 DTM while the 1971 DTM had almost no gaps.

All DTMs need to be carefully co-registered in order to minimize biases. First, tilts were eliminated based on calculated trend surfaces using stable terrain [12, 42]. Thereafter the DTM were horizontally and vertically coregistered following [37]. Values $\pm 60 \mathrm{~m}$ (which is similar to $3 \sigma$ of the DTM differences of the stable terrain) were omitted assuming that larger deviations are unrealistic for glaciers [cf. 15, 26]. Data voids were filled with the 
Table 2. Change in glacier area 1964-2010

\begin{tabular}{|l|c|c|c|c|c|}
\hline \multicolumn{1}{|c|}{ Показатели } & 1964 & 1971 & 1994 & 2003 & 2010 \\
\hline Area, $\mathrm{km}^{2}$ & $40.9 \pm 1.8$ & $39.9 \pm 0.9$ & $35.8 \pm 3.2$ & $34.6 \pm 1.7$ & $33.4 \pm 0.8$ \\
\hline $\mathrm{Da} /$ period, $\mathrm{km}^{2}$ & - & $-1.0 \pm 2.0$ & $-4.1 \pm 3.3$ & $-1.2 \pm 3.6$ & $-1.2 \pm 1.9$ \\
\hline$\Delta \mathrm{a} / \mathrm{yr}$ rel, \% & - & $-0.27 \pm 0.68$ & $-0.45 \pm 0.37$ & $-0.37 \pm 1.0$ & $-0.49 \pm 0.77$ \\
\hline$\Delta \mathrm{a}$ (rel.) since 1964, \% & - & $-2.4 \pm 6.3$ & $-12.5 \pm 9.0$ & $-15.4 \pm 6.0$ & $-18.3 \pm 5.0$ \\
\hline
\end{tabular}

mean value of the surrounding pixels in the ablation region and no vertical changes were assumed for the voids in the upper accumulation area. The uncertainty was estimated based on the Normalized Median Absolute Deviation (NMAD) of the non-glacierized terrain with a slope less than $25^{\circ}[12,43]$. Higher slopes were omitted as it is known that the uncertainty strongly increases for steep slopes. The NMAD is more robust and less influenced by outliers than the typically used standard deviation and also proven to be a suitable measure of the uncertainty for volumetric change assessments. Glacier volume changes were converted to mass using a density of $850 \pm 60 \mathrm{~kg} \mathrm{~m}^{-3}$ [cf. 30].

In order to estimate the glacier volume and the thickness distribution the glacier bed topography was calculated following the approach by [33] which needs as an input a DTM and digital branch lines only. The approach is based on the shallow ice approximation [18]. The glacier thickness is mainly dependent on the glacier slope $(\alpha)$ and the basal shear stress $(\tau)$ and can be calculated as follows:

$d=\tau /(\rho g f \sin \alpha)$

with $\rho$ being the ice density $\left(900 \mathrm{~kg} \mathrm{~m}^{-3}\right), g$ the gravitational acceleration $\left(9.81 \mathrm{~m} \mathrm{~s}^{-2}\right)$. The variable $f$ is the glacier shape factor and was set to 0.8 which is typical for valley glaciers. The basal shear stress was calculated following [28] based on the vertical distance of a glacier with a maximum stress of $150 \mathrm{hPa}$. The glacier volume was only calculated for the glaciers larger than $0.5 \mathrm{~km}^{2}$ as the uncertainty especially for the very small glaciers is high. However, these glaciers have usually a thickness of few a metres only and contribute, hence, only very little to the overall ice volume which is well within the estimated uncertainty of $30 \%$ [33].

\section{Results}

Glacier characteristics and area change. Fifty-one glaciers larger than $0.02 \mathrm{~km}^{2}$ with an overall area of $40.9 \pm 1.8 \mathrm{~km}^{2}$ were identified on the 1964 Corona KH-4A image. Glaciers smaller than
Table 3. Glacier area change with respect to the size classes

\begin{tabular}{|l|c|c|c|c|c|c|c|}
\hline \multirow{2}{*}{ Size class } & \multicolumn{2}{|c|}{ Glaciers 1964} & \multicolumn{2}{|c|}{ Area, $\mathrm{km}^{2}$} & \multicolumn{2}{c|}{$\begin{array}{c}\% \text { of } \\
\text { total area }\end{array}$} & \multicolumn{2}{c|}{ Area change } \\
\cline { 2 - 8 } & count & $\begin{array}{c}\% \text { of } \\
\text { total }\end{array}$ & 1964 & 2010 & 2010 & $\mathrm{~km}^{2}$ & $\%$ \\
\hline$<0.2$ & 31 & 62 & 2.1 & 1.1 & 3.2 & -1.0 & -48.6 \\
\hline $0.2-<0.5$ & 10 & 8 & 3.6 & 1.7 & 4.9 & -1.6 & -49.4 \\
\hline $0.5-<1.0$ & 2 & 4 & 1.5 & 1.3 & 3.8 & -0.3 & -17.4 \\
\hline $1.0-<5.0$ & 5 & 10 & 16.4 & 14.1 & 42.4 & -2.3 & -13.9 \\
\hline 5.0 & 3 & 6 & 17.3 & 15.2 & 45.7 & -2.1 & -12.1 \\
\hline Total & 51 & 100 & 40.5 & 33.3 & 100 & -6.5 & -18.3 \\
\hline
\end{tabular}

$0.5 \mathrm{~km}^{2}$ comprise $80 \%$ of the glacier number but only $\sim 13 \%$ of the total ice cover (Table 2 ). In contrast, the three largest glaciers with an area $>5 \mathrm{~km}^{2}$ cover $\sim 43 \%$. Overall, the glaciers in Ala Archa Valley vacated an area of $7.5 \pm 2.0 \mathrm{~km}^{2}(18.3 \pm 5.0 \%)$ during the period 1964-2010 (Table 3). The number of glaciers increased from 51 to 62 due to disintegration of several glaciers. The glaciers shrank during all investigated sub-periods with the lowest shrinkage rates measured between 1964 and 1971 (see Fig. 2). Until 2010, the small glaciers lost on average almost $50 \%\left(\sim 1.1 \% \mathrm{a}^{-1}\right)$ of their initial area while the large glaciers shrank only $\sim 13 \%$ $\left(\sim 0.3 \% \mathrm{a}^{-1}\right)$. These are typical glacier characteristics and can also be found in other parts of Northern Tien Shan (Ile and Kungöy Alatau [2, 11]) and many other mountain ranges on Earth [e.g. 13, 40]. However, the rates of change vary (Fig. 3).

Glacier volume and mass changes. Glaciers in Ala Archa Valley contained $1.56 \pm 0.47 \mathrm{~km}^{3}$ of ice in the year 2000 which leads to an average thickness of about 46 metres. Ak-Say $\left(0.35 \pm 0.10 \mathrm{~km}^{3}\right)$ and Golubin $\left(0.32 \pm 0.09 \mathrm{~km}^{3}\right)$ are the glaciers with the largest ice volume. Ak-Say, Golubin, Tuyuk and TopKaragay glaciers have likely a maximum thicknesses of around $200 \mathrm{~m}$ and above (Fig. 4).

The glaciers in Ala Archa Valley showed a clear volume and mass loss during the 1964-2012 period (Table 4, Fig. 5). Overall, the glaciers lost a vol- 


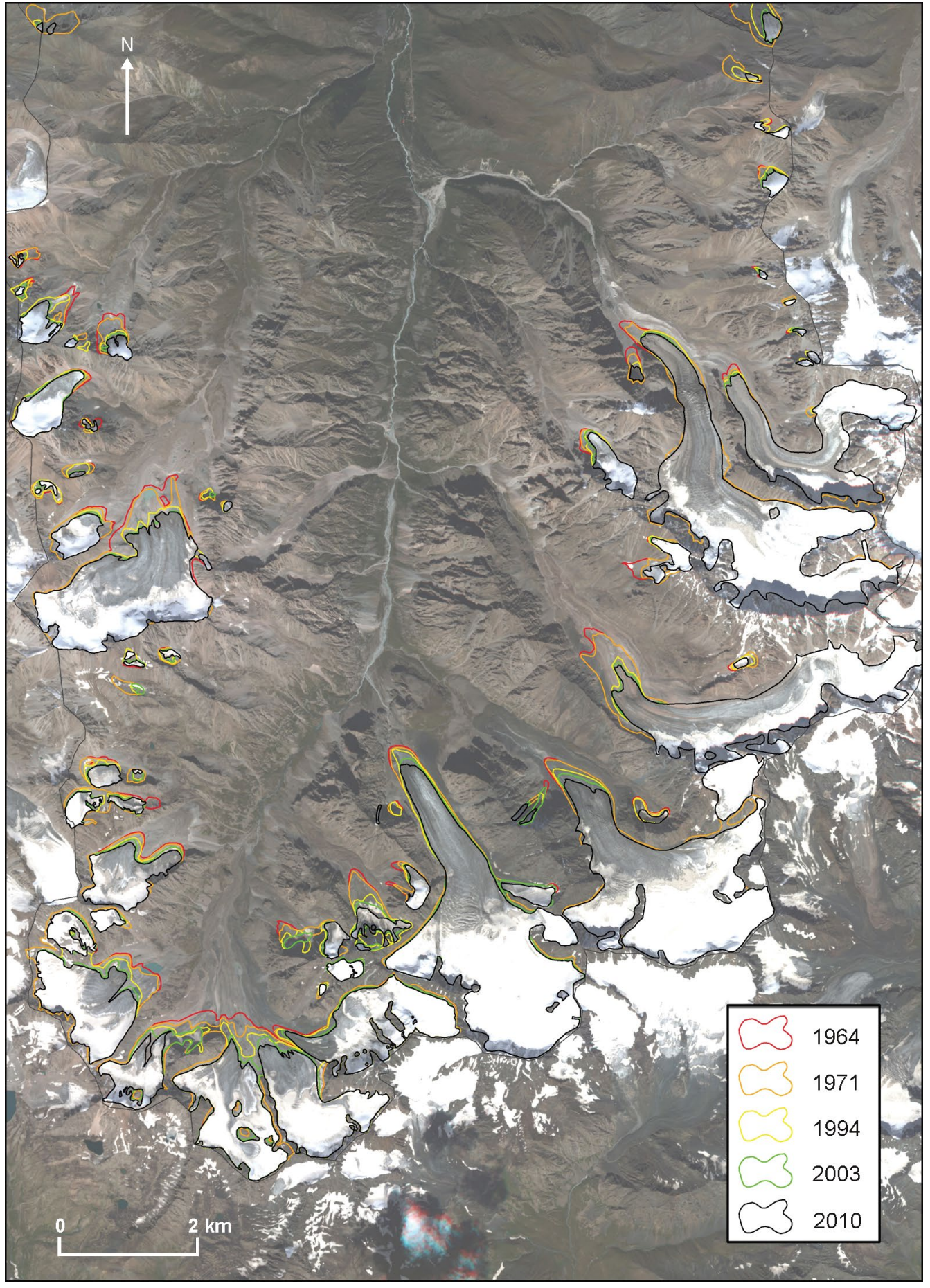

Fig. 3. Changes in glacier area 1964-2010. Background: Rapid Eye image from 2010 in natural colours

Рис. 3. Изменения плошади ледников в 1964-2010 гг.

В качестве фона использован снимок Rapid Eye 2010 г. в естественных цветах ume of $0.98 \pm 0.56 \mathrm{~km}^{3}$ in the last approximately 50 years. This is almost two thirds of the estimated volume in 2000 . The average mass balance was $\sim-0.45 \mathrm{~m}$ w.e. $\mathrm{a}^{-1}$ since 1964 . The mass loss of especially Golubin Glacier and most of the other glaciers was likely less in in the 1999-2012 period than before. However, the differences are not significant considering the uncertainty (see Table 4). A possible slight mass gain $\left(\sim+0.05 \mathrm{~m}\right.$ w.e. $\left.\mathrm{a}^{-1}\right)$ was found between 1964 and 1971 for Golubina Glacier (Fig. 6) but the uncertainty is here much larger than the signal. Adygyne Glacier showed the highest mass loss of the investigated larger glaciers for both investigated periods $\left(\sim 0.66 \mathrm{~m}\right.$ w.e. $\left.\mathrm{a}^{-1}\right)$.

Discussion and conclusions. The presented results on area and area changes $(-18.3 \pm 5.0 \%$ or 


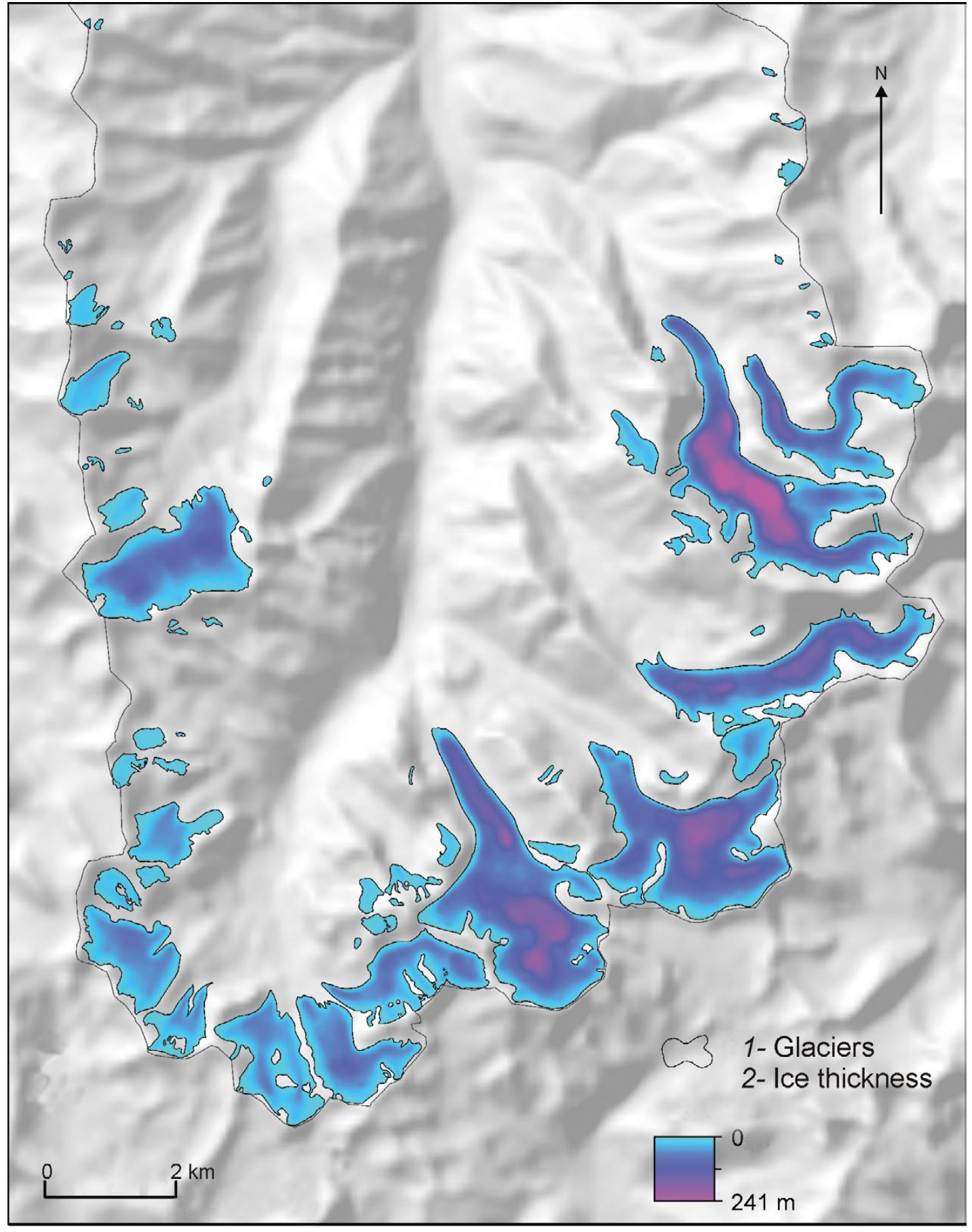

Fig. 4. Modelled glacier thickness Рис. 4. Толщина ледников, рассчитанная по модели:

1 - границы ледников; 2 - толщина льда, м
$-0.40 \pm 0.11 \% \mathrm{a}^{-1}$ for 1964 to 2010 ) is slightly higher than the previously published data based on aerial images and ASTER data: Aizen et al. [7] report glacier shrinkage from $42.8 \mathrm{~km}^{2}$ in 1963 to $36.3 \mathrm{~km}^{2}$ in $2003(\sim 15.1 \%)$. In contrast to [7] we only found two disappearing glaciers while [7] report a disappearance of nine. The reason for this difference could not be investigated. It might be the case that [7] mapped very small glaciers in 1963 which could not be iden- tified on the Corona images due to snow conditions. In contrast, [7] missed to include the debris-covered parts of Top-Karagay-glacier which we could identify using high-resolution imagery, DEM differencing results and the ALOS PALSAR coherence image.

Glacier shrinkage was similar $(\sim 16 \%)$ in Ile and Kungöy Ala-Too, which form the eastern part of the northern Tien Shan, for the period 1970-2007 based on similar high resolution data (Corona and 
Table 4. Glacier volume, elevation changes and mass balance of the glaciers $>0.5 \mathrm{~km}^{2}$ for the periods $1964-1999$ and $1999-2012$

\begin{tabular}{|l|c|c|c|c|c|c|c|}
\hline \multirow{2}{*}{ Glacier } & \multicolumn{3}{|c|}{ Periode 1964-1999 } & \multicolumn{4}{c|}{ Periode 1999-2012 } \\
\cline { 2 - 8 } & $\begin{array}{c}\text { Initial area, } \\
\mathrm{km}^{2}\end{array}$ & $\mathrm{dh}, \mathrm{m}$ & $\begin{array}{c}\mathrm{GMB}, \\
\mathrm{m} \mathrm{w.e.} \mathrm{a}^{-1}\end{array}$ & $\begin{array}{c}\text { Initial } \\
\text { area, } \mathrm{km}^{2}\end{array}$ & $\begin{array}{c}\text { Mean } \\
\text { thickness, } \mathrm{m}\end{array}$ & $\begin{array}{c}\text { GMB, } \mathrm{m} \\
\mathrm{m} \mathrm{w.e.} \mathrm{a}^{-1}\end{array}$ \\
\hline Aydgyne & 3.5 & $-29.9 \pm 12.2$ & $-0.68 \pm 0.28$ & 3.0 & -39.5 & $-8.0 \pm 8.0$ & $-0.65 \pm 0.65$ \\
\hline Golubin & 5.6 & $-23.1 \pm 12.2$ & $-0.46 \pm 0.24$ & 5.1 & -63.4 & $-2.3 \pm 8.0$ & $-0.28 \pm 0.97$ \\
\hline Tuyuk & 5.2 & $-21.9 \pm 12.2$ & $-0.48 \pm 0.27$ & 5.0 & -56.3 & $-5.5 \pm 8.0$ & $-0.49 \pm 0.71$ \\
\hline Top-Karagay* & 3.7 & $-23.3 \pm 12.2$ & $-0.40 \pm 0.21$ & 3.3 & -53.6 & $-7.2 \pm 8.0$ & $-0.42 \pm 0.47$ \\
\hline Ak-Say & 4.8 & $-22.4 \pm 12.2$ & $-0.58 \pm 0.32$ & 4.5 & -76.7 & $-3.3 \pm 8.0$ & $-0.35 \pm 0.85$ \\
\hline Uchitel & 2.2 & $-15.3 \pm 12.2$ & $-0.38 \pm 0.30$ & 2.0 & -40.9 & $-8.2 \pm 8.0$ & $-0.60 \pm 0.59$ \\
\hline All & 39.2 & $-20.5 \pm 12.2$ & $-0.45 \pm 0.27$ & 34.5 & -45.6 & $-5.1 \pm 8.0$ & $-0.42 \pm 0.66$ \\
\hline
\end{tabular}
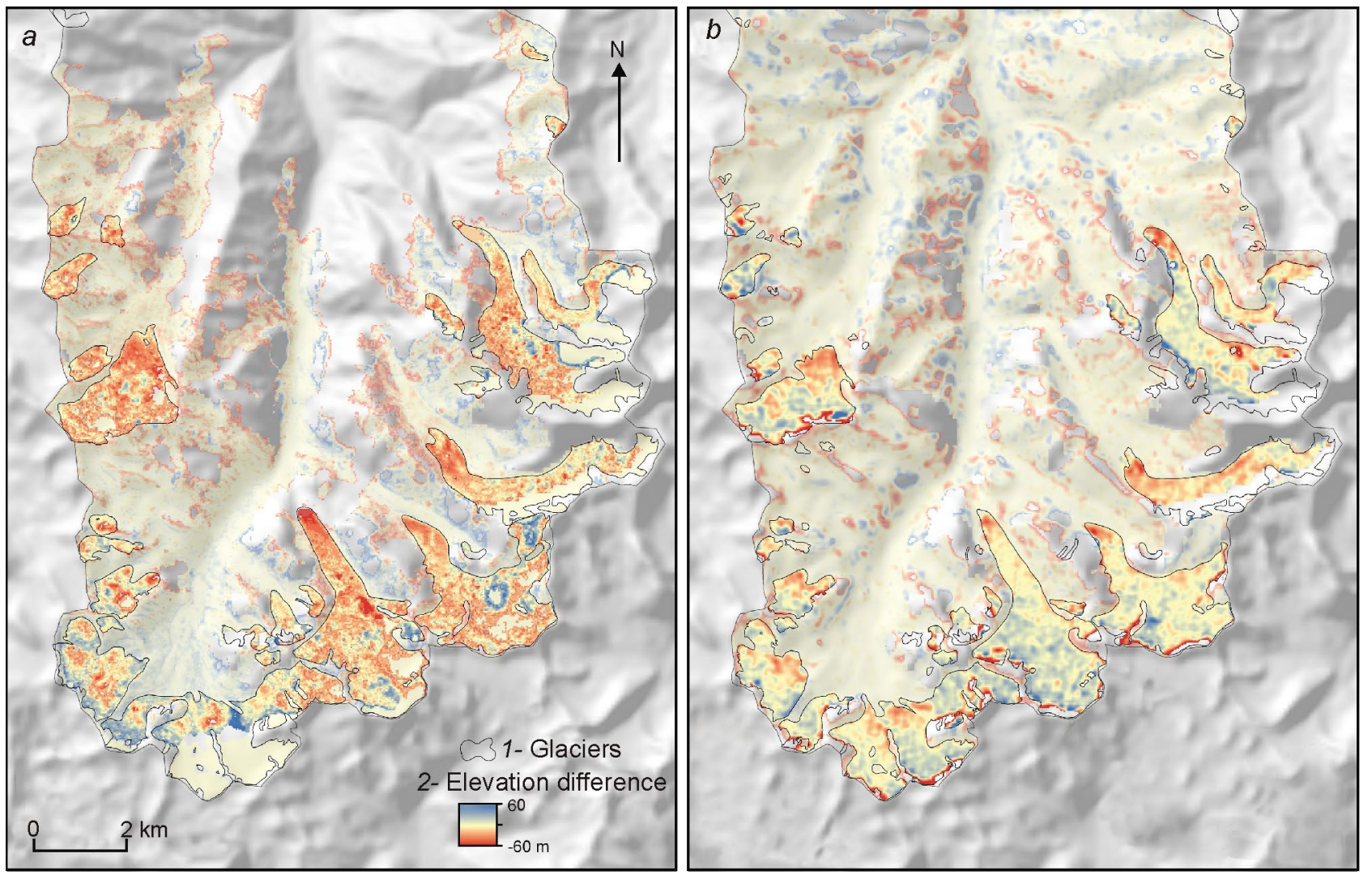

Fig. 5. DTM differences for the study area 1964-1999 (a), 1999-2012 (в)

Рис. 5. Разница ЦМР (цифровых моделей рельефа) для района исследования в 1964-1999 (a) и 1999-2012 гг. (в): 1 - границы ледников; 2 - разница высоты поверхности, м

ALOS) [35]. The glacier shrinkage is less than the reported $28.1 \%$ for the neighbouring Sokuluk watershed in the Kyrgyz Range for the period 1963 to 2000 [36]. The discrepancy can likely be explained by the overall significant smaller glacier size of the Sokuluk glaciers $\left(0.41 \mathrm{~km}^{2}\right.$ on average to $0.81 \mathrm{~km}^{2}$ in Ala Archa Valley). The glacier area loss is less in the dryer inner and central ranges of the Tien Shan with predominant summer precipitation where re- ported area loss varies between $0.30 \% \mathrm{a}^{-1}$ for 1965 to 2003 [31] and less than $0.1 \%$ for parts of Central Tien Shan [38].

This study shows the suitability of stereo Corona to generate DTMs and to assess glacier mass changes since the 1960s after careful co-registration. The terrain features are in general well represented and the glacier tongues can well be identified in the DTM difference image. Hence, stereo Corona has a high 


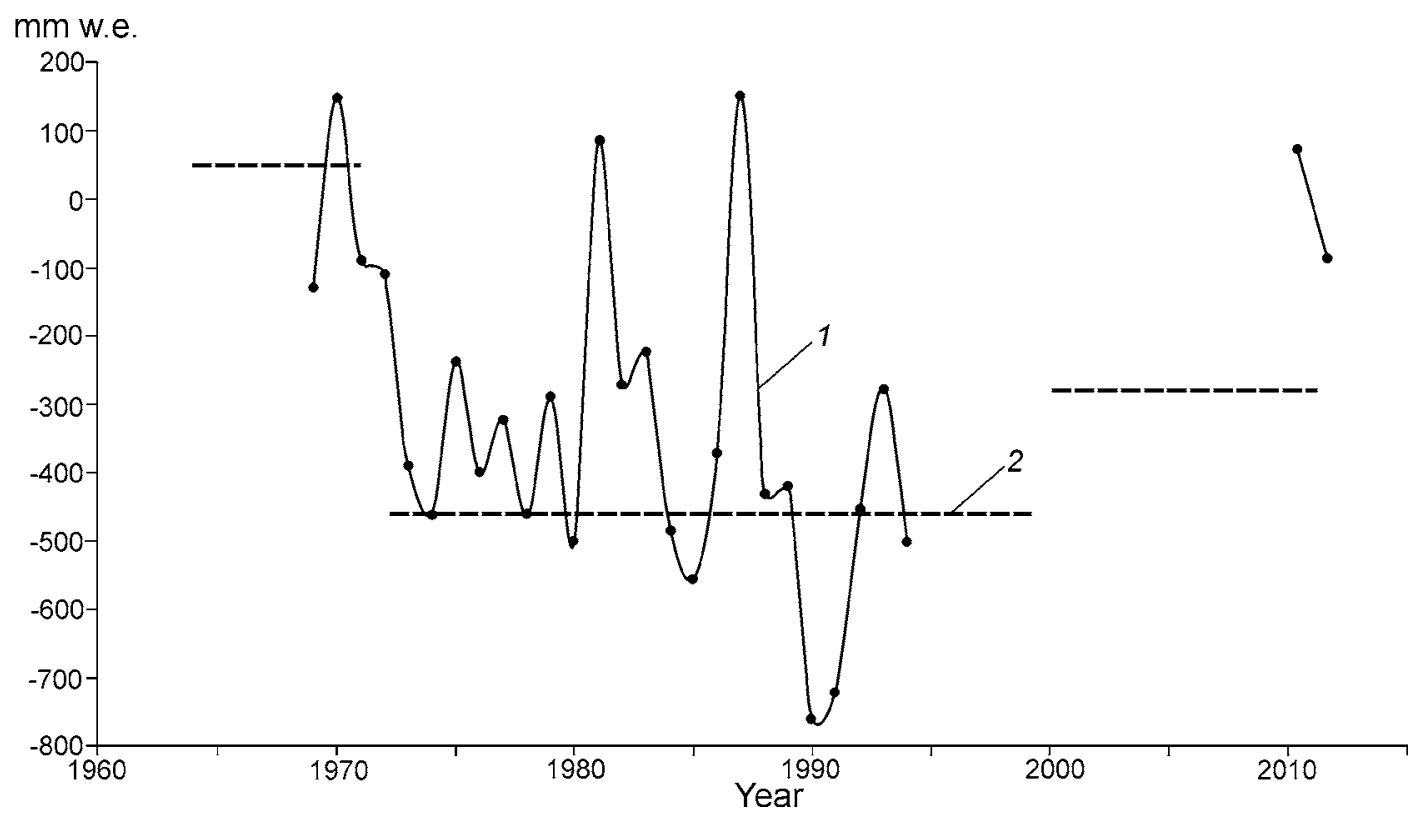

Fig. 6. Comparison of existing in-situ data (source: WGMS and CAIAG) (1) to the obtained geodetic mass balances of Golubin Glacier (2)

Рис. 6. Сравнение данных прямых измерений (источник: WGMS и ЦАИИЗ) (1) и полученного геодезического баланса массы ледника Голубина (2)

potential to significantly improve the knowledge of glacier mass changes during the last decades. While few studies use Corona to assess glacier length and area changes in Asia [e.g. 10, 35, 44] the application to volume changes since the publication of the pilot study by [12] is still very limited or restricted to small glacier parts [e.g. 32]. Similar, stereo declassified Hexagon data, which has a larger footprint, a resolution well below $10 \mathrm{~m}$ and is available since the mid 1970s, has huge potential especially of the territory of the former USSR, China and adjacent regions [48]. However, its application is also limited to a handful of publications with respect to glaciology [e.g. 14, 27, 43]. Soviet topographic maps have also been successfully applied to assess past glacier volume changes [3, 7]. DTM can also be generated from topographic maps to DTM generation using ASTER data is well established but the typical accuracy in mountainous terrain is $\pm 15 \mathrm{~m}$ or even worse [49]. However, careful co-registration and bias correction can improve the accuracy [37] making the ASTER DTMs not only suitable to detect significant volume changes for larger glaciers with a strong signal. The theoretical uncertainty as calculated based on the NMAD is especially for the comparison of the ASTER and SRTM DTM larger than the signal. However, the volume loss of the glacier tongues can be well identified from the surrounding stable terrain. This is similar also for the Corona DTMs and gives along with the general good agreement to the existing field measurements $[1,50]$ confidence about the reliability of the presented results.

The revealed mass loss of $0.46 \pm 0.24 \mathrm{~m} \mathrm{w.e.}^{-1}$ is slightly higher than the existing mass balance measurements with a mean value of $-0.33 \mathrm{~m}$ w.e. ${ }^{-1}$ for 1969 to $1994[1,50]$ but agrees well within the uncertainty. The reconstructed mass balance showed on average a slight mass gain from the late 1950s until 1970 [1] which is also in agreement with the results from the geodetic investigations despite the large uncertainty. For the period 1999 until 2012, a reduced mass loss was found which was likely due to increased accumulation identified in an elevation gain in the upper reaches of the glacier. Higher accumulation led also to a slight mass gain as measured for the mass balance year 2011 [50]. A slightly less negative mass balance in the first decade of the $21^{\text {st }}$ century than the decades before were also measured at Tuyuksu Glacier [50] in Ile Alatau, reported for the Central Tien Shan based on geodetic measurements [43, 45] and is also likely for other High Asian mountain ranges such as the Himalaya [16].

One important uncertainty is the unknown penetration of the c-band radar beam used for the SRTM 
DTM into snow and ice. I assumed a penetration of 2 metres which is in the range of the values estimated for the Himalaya and adjacent regions [26]. Comparing SRTM-C band with the X-band DTM (x-band has a much shorter wavelength than the c-band and, hence, only little penetration into snow and ice) for the same time revealed values of below $2 \mathrm{~m}$ in the ablation regions but values up to $5 \mathrm{~m}$ in the accumulation region [45]. An average penetration of $4 \mathrm{~m}$ instead of $2 \mathrm{~m}$ would lead to $0.13 \mathrm{~mm}$ w.e. ${ }^{-1}$ higher mass loss for 1999-2012 and a lower loss for the earlier period.

The applied method to estimate the glacier volume has likely similar uncertainties than the widely used area-volume scaling method $[4,8]$ in case the glacier outlines are of good quality. Unfortunately, in situ measurements were not available for the study region for calibration and validation. However, results of the same model applied for the Swiss Alps are in good agreement with measured thickness data [33]. Further advantages of the applied method are that it is physically based and variations of glaciers with the same size are captured. Ak-Say Glacier has likely a higher volume $\left(0.35 \pm 0.10 \mathrm{~km}^{3}\right)$ than Tuyuk Glacier $\left(0.28 \pm 0.08 \mathrm{~km}^{3}\right)$ although it is $0.5 \mathrm{~km}^{2}$ smaller (see Table 4). In addition, the distribution of the glacier thickness and overdeepenings can be identified. This is important for modelling the glacier recession and identifying possible future hazards [33]. Almost all glaciers show these overdeepenings which potentially could be filled by water with further glacier recession and hence, new potentially dangerous lakes could develop. Assuming similar mass loss rates of $\sim 0.45 \mathrm{~m}$ w.e. $\mathrm{a}^{-1}$ for the future, the glaciers might disappear within the next 100 years.

Acknowledgements. This study was conducted within the framework of the project «Spaceborne glacier monitoring of the Aksu-Tarim catchment (Xinjiang/ China, Kyrgzystan)» funded by Deutsche Forschungsgemeinschaft (DFG, Code BO 3199/2-1) and the Glaciers_cci project funded by European Space Agency (ESA, code (400010177810IAM). I thank A. Ender (Technische Universität Dresden) for the generation of the Corona DTMs, T. Strozzi (GAMMA RS) for providing the PALSAR coherence image, T. Pieczonka (Technische Universität Dresden) for support with the co-registration, A. Linsbauer (Universität Zürich) for the calculation of the glacier bed topography, and S. Kutusov (Inst. Geogr., RAS) for the Russian translation. I am grateful to V. Kuzmichenok (†, formely
IWP, Bishkek) and B. Moldobekov (CAIAG, Bishkek) for cooperation. The financial support of the attendance of the World Forum «Snow-2014», held January 2014 in Novosibirsk, where this paper was presented, is also acknowledged. The ASTER data were obtained for free from USGS under the Umbrella of the GLIMS project.

\section{References}

1. Айзен В.Б. Реконструкция баланса массы ледника Голубина // МГИ. 1988. № 62. С. 119-125.

2. Больх T., Марченко С.С. Значение ледников, каменных глетчеров и богатой льдом мерзлоты Северного Тянь-Шаня как водонапорной башни в условиях изменения климата // Снежно-ледовые и водные ресурсы высоких гор Азии: Материалы Междунар. семинара «Оценка снежно-ледовых и водных ресурсов Азии». 28-30 ноября 2006 г. / Ред. И.В. Северский. Алматы, 2007. С. 215-229.

3. Кутузов С.С. Изменение площади и объёма ледников хр. Терскей Ала-Тоо во второй половине ХХ в. // Лёд и Снег. 2012. № 1 (117). С. 5-14.

4. Мачерет Ю.Я., Кутузов С.С., Мацковский В.В., Лаврентьев И.И. Об оценке объёма льда горных ледников // Лёд и Снег. 2013. № 1 (121). С. 5-15.

5. Aizen V.B., Kuzmichenok V.A., Aizen E.M., Melack J.M. Characteristics of runoff formation at the Kirgizskiy Alatoo, Tien Shan // IAHS Publication. 1995. V. 228. P. 413-430.

6. Aizen V.B., Aizen E.M., Melack J.M. Precipitation, melt and runoff in the northern Tien Shan // Journ. of Hydrology. 1996. V. 186. P. 229-251.

7. Aizen V.B., Kuzmichenok V.A., Surazakov A.B., Aizen E.M. Glacier changes in the Tien Shan as determined from topographic and remotely sensed data // Global and Planetary Change. 2007. V. 56. P. 328-340.

8. Bahr D.B., Meier M.F., Peckham S.D. The physical basis of area volume scaling // Journ. of Geophys. Research. 1997. V. 102. P. 20,355-20,362.

9. Berthier E., Arnaud Y., Kumar R., Ahmad S., Wagnon P., Chevallier $P$. Remote sensing estimates of glacier mass balances in the Himachal Pradesh (Western Himalaya, India) // Remote Sensing of Environment. 2007. V. 108. P. 327-338.

10. Bhambri R., Bolch T., Chaujar R.K., Kulshreshtha S.C. Glacier changes in the Garhwal Himalayas, India 1968-2006 based on remote sensing // Journ. of Glaciology. 2011. V. 57. P. 543-556.

11. Bolch $T$. Climate change and glacier retreat in northern Tien Shan (Kazakhstan/Kyrgyzstan) using remote sensing data // Global and Planetary Change. 2007. V. 56. P. 1-12.

12. Bolch T., Buchroithner M.F., Pieczonka T., Kunert A. Planimetric and volumetric Glacier changes in Khumbu Hima- 
laya since 1962 using Corona, Landsat TM and ASTER data // Journ. of Glaciology. 2008. V. 54. P. 592-600.

13. Bolch T., Menounos B., Wheate R.D. Landsat-based inventory of glaciers in western Canada, 1985-2005 // Remote Sensing of Environment. 2010. V. 114. P. 127-137.

14. Bolch T., Yao T., Kang S., Buchroithner M.F., Scherer D., Maussion F., Huintjes E., Schneider C. A glacier inventory for the western Nyainqentanglha Range and Nam Co Basin, Tibet, and glacier changes 19762009 // Cryosphere. 2010. V. 4. P. 419-433.

15. Bolch T., Pieczonka T., Benn D.I. Multi-decadal mass loss of glaciers in the Everest area (Nepal, Himalaya) derived from stereo imagery // Cryosphere. 2011. V. 5. P. 349-358.

16. Bolch T., Kulkarni A., Kääb A., Huggel C., Paul F., Cogley J.G., Frey H., Kargel J.S., Fujita K., Scheel M., Bajracharya S., Stoffel M. The state and fate of Himalayan glaciers // Science. 2012. V. 336. P. 310-314.

17. Cao M. Detection of abrupt changes in glacier mass balance in the Tien Shan Mountains // Journ. of Glaciology. 1998. V. 44. P. 352-358.

18. Cuffrey K., Paterson, W.S.B. The Physics of Glaciers. $4^{\text {th }}$ edition. Academic Press, 2010. $704 \mathrm{p}$.

19. Dashora A., Lohani B., Malik J.N. A repository of earth resource information - CORONA satellite programme // Current Science. 2007. V. 92. P. 926-932.

20. Ding Y., Liu S., Li J., Shangguan D. The retreat of glaciers in response to recent climate warming in western China // Annals of Glaciology. 2006. V. 43. P. 97-105.

21. Ender A. Glacier volume and mass balance in the Ala Archa National Park (Kyrgyz Ala-Too/Kyrgyzstan). Diploma thesis, TU Dresden. 2010. $110 \mathrm{p}$.

22. Farinotti D., Huss M., Bauder A., Funk M., Truffer M. A method to estimate ice volume and ice thickness distribution of alpine glaciers // Journ. of Glaciollogy. 2009. V. 55. P. 422-430.

23. Farr T.G., Rosen P.A., Caro E., Crippen R., Duren R., Hensley S., Kobrick M., Paller M., Rodriguez E., Roth L., Seal D., Shaffer S., Shimada J., Umland J., Werner M., Oskin M., Burbank D., Alsdorf D. The Shuttle Radar Topography Mission // Review Geophysics. 2007. V. 45. RG2004. doi: 10.1029/2005RG000183.

24. Frey H., Paul F., Strozzi T. Compilation of a glacier inventory for the western Himalayas from satellite data: methods, challenges, and results // Remote Sensing of Environment. 2012. V. 124. P. 832-843.

25. Gardelle J., Berthier E., Arnaud Y. Impact on resolution and radar penetration on glacier elevation changes computed from DEM differencing // Journ. of Glaciology. 2012. V. 58. P. 419-422.

26. Gardelle J., Berthier E., Arnaud Y., Kääb A. Regionwide glacier mass balances over the Pamir-KarakoramHimalaya during 1999-2011 // Cryosphere. 2013. V. 7. P. 1263-1286.

27. Grant K.L., Stokes C.R., Evans I.S. Identification and characteristics of surge-type glaciers on Novaya Zem- lya, Russian Arctic // Journ. of Glaciology. 2009. V. 55. P. 960-972.

28. Haeberli W., Hoelzle M. Application of inventory data for estimating characteristics of and regional climatechange effects on mountain glaciers: a pilot study with the European Alps // Annals of Glaciology.1995. V. 21. P. 206-212.

29. Hagg W., Braun L., Kuhn M., Neesgaard T.I. Modelling of hydrological response to climate change in glacierized Central Asian catchments // Journ. of Hydrology. 2007. V. 332. P. 40-53.

30. Huss $M$. Density assumptions for converting geodetic glacier volume change to mass change // Cryosphere. 2013. V. 7. P. $877-887$.

31. Kutuzov S., Shahgedanova M. Glacier retreat and climatic variability in the eastern Terske-Alatoo, inner Tien Shan between the middle of the 19th century and beginning of the 21st century // Global and Planetary Change. 2009. V. 69. P. 59-70.

32. Lamsal D., Sawagki T., Watanabe T. Digital terrain modelling using Corona and ALOS PRISM data to investigate the distal part of Imja Glacier, Khumbu Himal, Nepal // Journ. of Mountain Sciences. 2011. V. 8. P. 390-402.

33. Linsbauer A., Paul F., Haeberli W. Modeling glacier thickness distribution and bed topography over entire mountain ranges with GlabTop: Application of a fast and robust approach // Journ. of Geophys. Research. 2012. V. 117. F03007. doi: 10.1029/2011JF002313.

34. McDonald R.A. CORONA: Success for space reconnaissance. A look into the Cold War, and a revolution for intelligence // Photogrammetric Engineering Remote Sensing. 1995. V. 61. P. 689-720.

35. Narama C., Kääb A., Duishonakunov M., Abdrakhmatov $K$. Spatial variability of recent glacier area changes in the Tien Shan Mountains, Central Asia, using Corona (1970), Landsat (2000), and ALOS (2007) satellite data // Global and Planetary Change. 2010. V. 71. P. 42-54.

36. Niederer P., Bilenko V., Ershova N., Hurni H., Yerokhin $S$., Maselli $D$. Tracing glacier wastage in the Northern Tien Shan (Kyrgyzstan/Central Asia) over the last 40 years // Climatic Change. 2008. V. 86. P. 227-234.

37. Nuth C., Kääb A. Co-registration and bias corrections of satellite elevation data sets for quantifying glacier thickness change // Cryosphere. 2011. V. 5. P. 271-290.

38. Ozmonov A., Bolch T., Xi C., Wei J., Kurban A. Glaciers characteristics and changes in the Sary-Jaz River Basin (Central Tien Shan) 1990-2010 Remote Sensing Letters // Remote Sensing Letters. 2013. V. 4. P. 725-734.

39. Paul F., Kääb A., Maisch M., Kellenberger T., Haeberli $W$. The new remote sensing derived Swiss Glacier Inventory: I. Methods // Annals of Glaciology. 2002. V. 34. P. 355-361.

40. Paul F., Kääb A., Maisch M., Kellenberger T., Haeberli $W$. Rapid disintegration of Alpine glaciers observed 
with satellite data // Geophys. Research Letters. 2004. V. 31. L21402. doi: 10.1029/2004GL020816.

41. Paul F., Haeberli $W$. Spatial variability of glacier elevation changes in the Swiss Alps obtained from two digital elevation models // Geophys. Research Letters. 2008. V. 35. L21502. doi: 10.1029/2008GL034718.

42. Pieczonka T., Bolch T., Buchroithner M.F. Generation and evaluation of multitemporal digital terrain models of the Mt. Everest area from different optical sensors // ISPRS Journ. of Photogrammetry. 2011. V. 66. P. 927-940.

43. Pieczonka T., Bolch T., Wei J., Liu S. Heterogeneous mass loss of glaciers in the Aksu-Tarim Catchment (Central Tien Shan) revealed by 1976 KH-9 Hexagon and 2009 SPOT-5 stereo imagery // Remote Sensing of Environment. 2013. V. 130. P. 233-244.

44. Schmidt S., Nüsser M.. Changes of High Altitude Glaciers from 1969 to 2010 in the Trans-Himalayan Kang Yatze Massif, Ladakh, Northwest India // Arctic, Antarctic and Alpine Research. 2012. V. 44. P. 107-121.

45. Shangguan D., Bolch T., Ding Y., Pieczonka T., Kröhnert M., Wetzel H.-U., Liu S. Elevation changes of Inylchek Glacier during 1974-2007, Central Tian Shan, Kyrgyzstan derived from remote sensing data // Cryosphere Discussion. 2014. V. 8. P. 2573-2610.

46. Solomina O., Barry R., Bodnya M. The retreat of Tien Shan glaciers (Kygryzstan) since the Little Ice Age estimated from aerial photographs, lichenometric and historical data // Geogr. Annals. A. 2004. V. 86. P. 205-216.

47. Sorg A., Bolch T., Stoffel M., Solomina O., Beniston M. Climate change impacts on glaciers and runoff in Tien Shan (Central Asia) // Nature Climate Change. 2012. V. 2. P. 725-731.

48. Surazakov A., Aizen V.B. Positional accuracy evaluation of declassified Hexagon KH-9 mapping camera imagery // Photogrammetric Engineering Remote Sensing. 2010. V. 76. P. 603-608.

49. Toutin T. ASTER DEMs for geomatic and geoscientific applications: a review // Intern. Journ.of Remote Sensing. 2008. V. 29. P. 1855-1875.

50. WGMS. Glacier Mass Balance Bulletin No. 12 (20102011) / Eds. M. Zemp, S.U. Nussbaumer, K. Naegeli, I.F. Gärtner-Roer, P.M. Hoelzle, W. Haeberli. ICSU(WDS)/IUGG(IACS)/UNEP/UNESCO/

WMO. Zürich, Switzerland: World Glacier Monitoring Service, 2013. $106 \mathrm{p}$.

51. Zemp M., Jansson P., Holmlund P., Gärtner-Roer I., Koblet T., Thee P., Haeberli $W$. Reanalysis of multi-temporal aerial images of Storglaciären, Sweden (1959-99) Pt. 2: Comparison of glaciological and volumetric mass balances // Cryosphere. 2010. V. 4. P. 345-357.

\section{Изменение площади и массы ледников в долине Ала-Арча в Киргизском хребте на Северном Тянь-Шане с 1964 г.}

Ледники - важный источник пресной воды в Средней Азии, поскольку максимальный ледниковый сток отмечается в летние месяцы, когда количество осадков минимально, а потребности в воде - максимальны. Многие исследования посвящены изменению площади ледников Тянь-Шаня, однако для оценки речного стока и влияния климатических изменений необходимы данные об изменении массы льда. Несмотря на важность таких исследований, до сих пор подобные работы выполнены лишь на небольшом числе ледников. Оценки баланса массы геодезическими методами могут дополнить и продлить существующие ряды прямых измерений на ледниках. В данной работе оценены изменения площади и массы ледников, расположенных в долине Ала-Арча в Киргизском Тянь-Шане, с помощью стереоснимков спутника Corona 1964 и 1971 гг., стереоснимков ASTER 2012 г., цифровой модели земной поверхности SRTM, а также других оптических данных, среди которых LANDSAT ETM+ или RapidEye. Дополнительно было выполнено моделирование толщины льда исходя из напряжения сдвига на ложе и рельефа поверхности ледников. Результаты показали, что с 1964 по 2010 г. ледники непрерывно сокращались и потеряли $18,3 \pm 5,0 \%$ общей площади. Средний баланс массы составлял $-0,45 \pm 0,27$ м в.э. в год для периода с 1964 по 1999 г. и $-0,42 \pm 0,66$ м в.э. в год в 19992012 гг. Для ледника Голубина зарегистрировано незначительное накопление массы в 19641971 гг. и замедление сокращения массы в 1999-2012 гг. Эти результаты согласуются с существующими данными прямых измерений баланса массы, проводившихся с 1962 по 1994 г. и с 2010 г. По состоянию на 2000 г. общий объём льда составлял 1,56 $\pm 0,47$ км$^{3}$. Таким образом, если масса льда будет сокращаться с такой же скоростью, то к 2100 г. ледники в районе исследования полностью растают. 